\title{
Penurunan Kecemasan melalui Senam Prolanis Pada Lansia
}

\author{
Ike Prafitasari , Nurul Mawaddah, Oktovian Dwi Arini \\ Email: ikkeshary@gmail.com \\ Nursing S1 Study Program, STIKES Majapahit Mojokerto, Indonesia \\ Jln Raya Gayaman Km 02 Jabon Mojoanyar Mojokerto \\ Telp/Fax: (0321) 329921
}

\begin{abstract}
Abstrak
Indonesia sudah memasuki fase negara berstruktur tua karena memiliki penduduk lansia yang mencapai 9,27\% dari total penduduk. Masalah kecemasan mengalami peningkatan prevalensi pada golongan lansia karena kemunduran fisik dan mental yang dialami. Senam prolanis adalah satu bentuk latihan fisik sedang untuk mengatasi kecemasan pada lansia. Penelitian ini bertujuan untuk mengetahui pengaruh senam prolanis terhadap kecemasan pada lansia di wilayah kerja puskesmas Sumberbaru. Desain penelitian ini yaitu pre eksperimental dengan teknik total sampling dengan jumlah sampel 29 orang anggota prolanis. Analisa data yang digunakan yaitu uji statistik paired ttest. Hasil penelitian didapatkan sebelum senam prolanis skor kecemasan rata-rata 19,76, artinya sebagian besar berada pada tingkat kecemasan ringan. Setelah senam prolanis kecemasan lansia rata-rata 18,10, artinya hampir separuhnya berada pada tingkat kecemasan ringan. Berdasarkan uji statistic dengan taraf signifikansi $\alpha=0,05$, diperoleh hasil $p$ value 0,000 . Karena nilai $\mathrm{p}<\alpha(0,05)$, maka Ho ditolak. Jadi ada pengaruh senam prolanis terhadap kecemasan pada lansia di Puskesmas Sumberbaru.Kegiatan senam prolanis membentuk interaksi sosial diantara para lansia sehingga lansia tidak merasa terisolasi. Senam prolanis juga meningkatkan penyerapan oksigen, manajemen nyeri, dan memicu hormone endorfin untuk menciptakan rasa tenang sehingga mengurangi kecemasan pada lansia.
\end{abstract}

Kata kunci: senam prolanis; kecemasan; lansia.

\begin{abstract}
Indonesia has reached the phase of the old structured country because it has an elderly population which reaches $9.27 \%$ of the total population. Problems experienced were increasing due to the prevalence in the elderly due to decrease capability of physical and mental. Prolanist exercises a form of physical exercise that was overcoming adversity in the elderly. This study aimed to study the effect of prolanist exercises on anxiety in the elderly in the working area of the Sumberbaru Health Center. The design of this study was pre-experimental with a total sampling technique with a total sample of 29 prolanist members. Analysis of the data used was a paired t-test statistical test. The results obtained before prolanis exercises most of the elderly were at mild anxiety levels, with an average HARS score of 19.76. After prolanis exercises the elderly anxiety almost half are in the level of mild anxiety, with an average HARS score of 18.10. Based on statistical tests with a significance level of $\alpha=0.05$, the results obtained $p$ value 0,000 . Because the value of $p<\alpha(0.05)$, Ho was rejected. So there was an effect prolanist exercises for anxiety the elderly at the Sumberbaru Health Center. Prolanis exercises activities created social interaction between the elderly so that the elderly cannot feel isolated. Prolanis exercises also increase oxygen absorption, pain management, and trigger endorphins to created a sense of calm thereby reducing anxiety in the elderly.
\end{abstract}

Keywords: prolanist exercises; anxiety; elderly. 
Jurnal Kebidanan Harapan Ibu Pekalongan

\section{Pendahuluan}

Salah satu kelompok rentan dalam masyarakat baik secara kesehatan fisik maupun kesehatan mental yaitu kelompok lansia. Salah satu contoh masalah kesehatan mental yaitu kecemasan yang memiliki hubungan dengan latihan seharihari lansia dalam memenuhi kebutuhan hidupnya (Kusuma dan Ardani, 2018). Karena itu lansia memerlukan perawatan secara komprehensif.

Indonesia sudah memasuki fase negara berstruktur tua karena memiliki jumlah penduduk lansia yang mencapai $9,27 \%$ dari total penduduk. Karena Jumlah lansia di Indonesia mencapai 24,49 juta jiwa (Badan Pusat Statistik, 2018). Presentase penduduk lansia di Jawa Timur mencapai $12,25 \%$, sedangkan Jember memiliki presentase $12,95 \%$ dari total penduduk (BPS, 2018).

Masalah kecemasan mengalami peningkatan prevalensi pada golongan lansia karena kemunduran fisik dan mental yang dialami. Kecemasan pada lansia berhubungan dengan penyakit degeneratif yang diderita terutama penyakit jantung dan dimensia (Schuurmans \& Balkom, 2011).

$$
\text { Lansia memiliki }
$$

kecenderungan yang lebih tinggi untuk mengalami gangguan kecemasan daripada depresi (John W. Santrock, 2002 dalam Annisa dan Ifdil, 2016). Masalah mental kecemasan pada lansia juga terjadi karena masalah sosial yang ada terkait tidak tercapainya tugas perkembangan pada usia lansia untuk beradaptasi dengan perubahan yang terjadi (Asmadi, 2012). Kecemasan pada lansia juga timbul karena terjadi perubahan struktur tubuh (Boltz, dkk., 2012). Latihan fisik berupa senam dapat mengatasi kecemasan pada lansia karena latihan fisik berupa kegiatan senam dapat memicu endorfin, zat kimia otak yang menekan rasa nyeri, menimbulkan perasaan tenang dan meningkatkan semangat hidup (Kholifah, 2016). Dalam kegiatan prolanis terdapat latihan fisik yaitu berupa senam pada lansia. Salah satu layanan kesehatan primer yang menyelenggarakan prolanis adalah Puskesmas Sumberbaru.Oleh karena itu penulis tertarik untuk melakukan penelitian terkait pengaruh senam prolanis terhadap kecemasan pada lansia di wilayah kerja Puskesmas Sumberbaru.

\section{Metode Penelitian}

Rancangan penelitian yang digunakan adalah penelitian preeksperimental.Anggota Prolanis sebanyak 29 orang. Teknik sampling menggunakan teknik Total sampling sebanyak 29 sampel. Perlakuan yang diberikan pada penelitian ini yaitu senam prolanis.Instrumen penelitian ini menggunakan Hamilton Rating Scale For Anxiety (HARS). Perhitungan uji statistik menggunakan paired $t$ test.

\section{Hasil Penelitian}

Penelitian ini dilakukan pada 28 Maret 2020 pada pkl. 06.00 WIB di Puskesmas Sumberbaru. 
Jurnal Kebidanan Harapan Ibu Pekalongan

A. Data Umum

Tabel 1. Distribusi Frekuensi Anggota Senam Prolanis

Berdasarkan Usia Di Puskesmas Sumberbaru

\begin{tabular}{ccc}
\hline $\begin{array}{c}\text { Usia Anggota } \\
\text { Prolanis }\end{array}$ & Frekuensi & prosentase \\
\hline Lansia awal & 6 & 20,7 \\
Lansia akhir & 8 & 27,6 \\
Manula & 15 & 51,7 \\
Total & 29 & 100 \\
\hline
\end{tabular}

Tabel 1. menunjukkan bahwa dari 29 responden, hampir setengah anggota senam prolanis berada pada usia manula $(51,7 \%)$.

Tabel 2. Distribusi Frekuensi Anggota Senam Prolanis Berdasarkan Jenis Kelamin Di Puskesmas Sumberbaru

\begin{tabular}{ccc}
\hline Jenis & Frekuensi & prosentase \\
Kelamin & & \\
\hline Laki-laki & 9 & 31,03 \\
Perempuan & 20 & 68,97 \\
Total & 29 & 100 \\
\hline
\end{tabular}

Tabel 2. menunjukkan bahwa dari 29 anggota senam prolanis, sebagian besar ber jenis kelamin perempuan $(68,97 \%)$.
Tabel 3. Distribusi Frekuensi Lingkungan Tempat Tinggal Anggota Senam Prolanis di Puskesmas Sumberbaru

\begin{tabular}{|c|c|c|}
\hline $\begin{array}{c}\text { Lingkungan Tempat } \\
\text { tinggal }\end{array}$ & Frekuensi & prosentase \\
\hline \multicolumn{3}{|l|}{ Kelompok perlakuan } \\
\hline $\begin{array}{l}\text { Tinggal bersama } \\
\text { keluarga inti }\end{array}$ & 21 & 72,41 \\
\hline $\begin{array}{l}\text { Tinggal bersama } \\
\text { bukan keluarga inti }\end{array}$ & 8 & 27,59 \\
\hline Tinggal sendirian & 0 & 0 \\
\hline Total & 29 & 100 \\
\hline \begin{tabular}{l}
\multicolumn{1}{c}{ Tabel } \\
bahwa \\
sampel p \\
bersama \\
$(72,41 \%)$.
\end{tabular} & $\begin{array}{l}\text { 3. menunju } \\
\text { sebagian } \\
\text { penelitian ti } \\
\text { keluarga }\end{array}$ & $\begin{array}{r}\text { ukkan } \\
\text { besar } \\
\text { inggal } \\
\text { inti }\end{array}$ \\
\hline
\end{tabular}

B. Data Khusus

Tabel 4. Analisis Perbedaan Kecemasan Lansia Sebelum Dan Sesudah Senam Prolanis Di Puskesmas Sumberbaru

\begin{tabular}{cccccccc}
\hline Variabel & N & Mean & Mean diff & Stand Dev & Nilai Min & Nilai Max & P value \\
\hline Pre test & 29 & 19,76 & \multirow{2}{*}{1,66} & 5,46 & 11 & 30 & \\
Post test & 29 & 18,10 & & 5,85 & 9 & 29 & 0,000 \\
\hline
\end{tabular}

Berdasarkan tabel 4. rata-rata nilai skor HARS pretest pada kelompok lansia sebelum senam prolanis yaitu 19,76 yang berarti sebagian besar memiliki tingkat kecemasan ringan (17 responden). Dengan skor kecemasan paling kecil 11 dan skor kecemasan paling besar 30 . Rata-rata nilai skor HARS posttest pada kelompok lansia sesudah senam 
Jurnal Kebidanan Harapan Ibu Pekalongan

prolanis yaitu 18,10 yang berarti hampir setengahnya kecemasan lansia sesudah senam prolanis berada pada tingkat kecemasan ringan (11 responden) . Dengan skor kecemasan paling kecil 9 dan skor kecemasan paling besar 29. Hampir seluruh responden mengalami penurunan skor kecemasan yaitu 28 responden (97\%). Hasil uji t tes dependent (paired $t$ test), didapatkan $\mathrm{p}$ value 0,000 . Karena nilai $p<\alpha$ $(0,05)$, maka Ho ditolak dan Ha diterima. Jadi ada perbedaaan skor kecemasan sebelum dan sesudah senam prolanis pada lansia di Puskesmas Sumberbaru. Jadi rata-rata responden mengalami penurunan skor kecemasan sebanyak 1,66 poin.

\section{Pembahasan}

\section{A. Analisis Kecemasan Lansia Sebelum Senam Prolanis \\ Rata-rata kecemasan skor HARS nilai pretest pada kelompok lansia yaitu 19,76. Dengan skor kecemasan paling kecil 11 dan skor kecemasan paling besar 30 . Rata-rata kecemasan lansia berada pada skor 19,76. Berdasarkan kategori tingkat kecemasan sebagian besar lansia mengalami kecemasan ringan. Ansietas merupakan respon emosional terhadap penilaian terhadap stimulus yang mengancam (Stuart, 2013).}

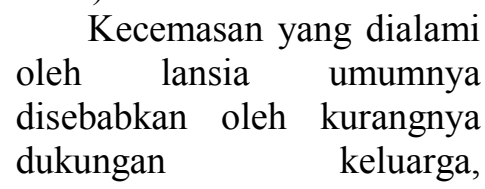

kurangnya dukungan sosial dan masalah penurunan kondisi fisik lansia (Redjeki dan Tambunan, 2019). Selain itu, masalah psikologis yang terjadi pada lanjut usia ini merupakan kondisi penurunan yang turut dipengaruhi oleh kesehatan fisik dengan persoalan mental seperti pola dan sikap hidup, merasa kesepian, perasaan tidak berharga, emosi yang meningkat pada lanjut usia, serta ketidakmampuan dalam menyesuaikan tugas perkembangan lanjut usia (Annisa \& Ifdil, 2016). Sedangkan menurut Institute on Aging (2018), kecemasan pada lansia timbul karena beberapa masalah yang timbul di usia lanjut diantaranya: pendapatan yang tidak stabil, masalah kesehatan, demensia, hilangnya independensi, pergantian peran, perencanaan akhir kehidupan, duka dan kehilangan, imobilitas, sakit kronis, perubahan persepsi sensorik, termasuk kehilangan kemampuan penglihatan dan pendengaran serta isolasi.

Pada data penelitian seluruh lansia tinggal bersama keluarga, jadi lansia kemungkinan memiliki dukungan keluarga yang baik. Namun, masalah yang mungkin dialami oleh lansia yang tinggal bersama anggota keluarganya yaitu pendapatan tidak stabil, pergantian peran, perencanaan akhir kehidupan, duka dan kehilangan. Lansia yang tinggal bersama anaknya dan telah kehilangan pasangan umumnya peran 
Jurnal Kebidanan Harapan Ibu Pekalongan

pengambilan keputusan di dalam keluarga telah berpindah kepada anaknya. Apabila lansia sudah mengalami penurunan kemampuan fisik maka keuangannya akan bergantung pada anak-anaknya. Oleh karena itu lansia yang tinggal dengan anggota keluarganya masih rentan mengalami kecemasan.

Lansia pada penelitian ini seluruhnya tinggal bersama anggota keluarga baik keluarga inti maupun keluarga besar. Baik keluarga inti maupun keluarga besar merupakan system dukungan utama bagi lansia. Lansia yang mengalami penurunan skor kecemasan tidak memiliki perbedaan baik yang tinggal bersama keluarga besar maupun keluarga inti. Karena lansia yang tinggal bersama keluarga inti maupun keluarga besar berfungsi sebagai system pendukung bagi anggota-anggotanya, sebab sifat gotong royong masyarakat kita dan cara hidup keluarga besar (exstended family) dan ptrilineal serta nilai-nilai, norma-norma mengenai keluarga sangat membantu anggota keluarga yang berusia lanjut (Anggraini, Kusuma, dan Widiani, 2017). Hal ini sesuai dengan data PBB di Indonesia pada 2017 sebagain besar lansia tinggal bersama keluarga besarnya (56,7 \%). Sisanya memilih tinggal dengan pasangan $(17 \%)$ dan anak-anaknya (12,5\%) (Pusparisa, 2020).

Masalah fisik yang diderita oleh lansia umumnya menimbulkan rasa nyeri dan tidak nyaman. Rasa nyeri timbul pada lansia dengan penyakit darah tinggi atau diabetes mellitus. Gangguan rasa nyaman pada lansia jika memiliki penurunan fungsi penglihatan dan pendengaran. Selain itu masalah fisik pada lansia dapat menimbulkan penurunan kemampuan lansia dalam melakukan aktivitas sehari-hari maupun hambatan untuk melakukan pemenuhan kebutuhan dasarnya. Keterbatasan-keterbatasan yang dialami lansia dapat menimbulkan perasaan tidak berdaya dan ketergantungan sehingga lansia menjadi cemas akan keadaannya. Oleh karena itu kecemasan pada lansia anggota prolanis terkait dengan penyakit fisiknya.

B. Analisis Kecemasan Lansia Sesudah Senam Prolanis

Kecemasan skor HARS nilai post test pada kelompok lansia yaitu 18,10. Dengan skor kecemasan paling kecil 9 dan skor kecemasan paling besar 29. Berdasarkan kategori tingkat kecemasan sesudah senam prolanis, lansia yang mengalami kecemasan sedang hampir separuhnya. Kecemasan pada lansia berhubungan dengan penyakit degeraratif yang diderita terutama penyakit jantung dan dimensia (Schuurmans \& Balkom, 2011). Beberapa cara yang dapat ditempuh untuk mengurangi kecemasan pada lansia misalnya membangun hubungan dengan sesama lansia atau bergabung dengan kelompok di masyarakat 
Jurnal Kebidanan Harapan Ibu Pekalongan

untuk menghindari rasa isolasi, sedangkan melakukan latihan fisik sebagai bentuk managemen nyeri kronik (Institute on Aging, 2018).

Kegiatan senam prolanis yang diikuti oleh lansia menjadi solusi dua masalah penyebab kecemasan pada lansia yaitu rasa isolasi dan masalah nyeri kronik. Dengan mengikuti kegiatan senam prolanis lansia bertemu dengan sebayanya dan dapat terjadi interaksi dan komunikasi selama kegiatan senam sehingga lansia tidak merasa sendirian menghadapi hari tua. Gerakan gerakan senam prolanis memberikan efek relaksasi, ketegangan otot juga akan berkurang sehingga tekanan darah lansia dengan hipertensi juga akan berkurang. Dengan terkontrolnya penyakit fisik yang diderita lansia anggota senam prolanis maka tingkat kecemasan terutama terkait penyakit fisik yang diderita juga akan berkurang maka skor HARS setelah senam akan berkurang.

Berdasarkan data skor kecemasan sesudah senam prolanis yang mengalami penurunan rata-rata 1,66 poin, jadi senam prolanis efektf untuk kecemasan ringan pada lansia. Senam prolanis kurang efektif untuk diberikan kepada lansia yang memiliki skor kecemasan tinggi dan masuk dalam kategori berat. Jika ada lansia memiliki kecemasan tinggi mungkin dapat memilih terapi Cognitive Behavior Therapy (CBT) (Okonkwo, 2017).

\section{Analisis Perbedaan Tingkat Kecemasan Lansia Sebelum dan Sesudah Senam Prolanis}

Hasil uji $t$ dependent didapatkan nilai $p$ value 0,000 . perbedaan rata-rata tingkat kecemasan $\mathrm{p}<\alpha$ $(0,05)$. Yaitu, ada perbedaan tingkat kecemasan lansia sebelum dan sesudah senam prolanis, dengan rata-rata penurunan skor kecemasan sebanyak 1,66 poin. Hasil temuan ini juga sesuai dengan penelitian yang dilakukan oleh Khamida dkk (2018), yang memberikan intervensi berupa senam Tai Chi. Berdasarkan hasil uji Wilcoxon senam Tai Chi dapat menurunkan tingkat kecemasan pada lansia.

Penelitian yang dilakukan oleh Herawati (2014) juga mengidentifikasi bahwa senam lansia mampu menurunkan tingkat kecemasan lansia di panti sosial Trisna Werdha. Penatalaksanaan senam prolanis pada penelitian ini dilakukan selama 1 minggu sekali, dan intensitas senam yang diberikan dengan kategori rendah pada rentan $60-75 \%$ dari denyut jantung maksimal. Manfaat dari senam prolanis yaitu untuk menjaga fungsi jantung supaya dapat bekerja secara optimal. Selain itu, aktivitas tersebut tidak hanya menyehatkan fisik tetapi juga dapat menjaga mental dan emosi. Aktivitasini setidaknya dapat mempertahankan emosi lansia tetap stabil, senantiasa bahagia, tidur lebih nyenyak serta mengkondisikan pikiran 
Jurnal Kebidanan Harapan Ibu Pekalongan

tetap segar. Penelitian ini, melakukan senam prolanis dengan durasi 15 - 60 menit. Karena menurut Herawati (2014), senam lansia yang dapat menurunkan tingkat kecemasan lansia memiliki efek yang sama dengan senam tera yang dilakukan lansia di Panti Tresna Werdha Hargo Dedali Surabaya yang juga dapat merunkan tingkat kecemasan pada lansia (Pradana, 2017). Penelitian yang dilakukan oleh Pasco, dkk (2011) melakukan latihan fisik berupa kegiatan senam secara teratur dapat mengurangi resiko munculnya gejala kecemasan. Studi yang dilakukan oleh Branco de Oliveira, dkk., (2019) terhadap dua kelompok, yang pertama tergabung dalam pusat latihan fisik dan satu kelompok lainnya berada dikomunitas tanpa mengikuti kegiatan pusat latihan fisik dan didapatkan hasil bahwa kelompok kedua memiliki tingkat kecemasan yang lebih tinggi.

Latihan fisik berupa senam berdasarkan beberapa studi terbukti menurunkan gejala kecemasan pada lansia. Gerakan-gerakan yang dilakukan dalam senam prolanis yang terdiri dari pemanasan, inti dan pendinginan. Gerakan senam prolanis dapat melatih sistem pernafasan, peregangan otot dan keseimbangan sehingga badan menjadi lebih rileks karena memicu hormon endorfin yang memberikan efek tenang sehingga rasa cemas pada lansia menjadi berkurang (Kholifah, 2016). Dengan berolahraga akan merangsang kelenjar pineal untuk mensekresi serotonin dan melatonin. Rangsangan tersebut diperoleh dari hipotalamus dan diteruskan ke pituitary untuk pembentukan beta endhorphin dan enkephalin.Dalam kondisi rileks, lansia akan mudah dalam memenuhi kebutuhan tidurnya. Melakukan aktivitas fisik seperti senam yang teratur dapat membakar glukosa melalui aktivitas otot yang akan menghasilkan ATP sehingga endhorphin akan muncul dan membawa rasa nyaman, senang, dan bahagia. Jadi senam yang dilakukan oleh lansia dapat menurunkan tingkat kecemasan baik lansia yang tinggal bersama keluarga maupun lansia yang tinggal dipanti sosial.

Penurunan skor kecemasan yang hanya 1,66 poin menurut peneliti terjadi karena dalam penelitian ini hanya dilakukan satu kali pengambilan data sebelum dan sesudah senam prolanis sehingga penurunan skor kecemasan pada lansia tidak maksimal. Namun jika pengukuran skor kecemasan dilakukan sebelum dan sesudah beberapa sesi senam prolanis memungkinkan didapatkan penurunan skor kecemasan yang lebih banyak.

Pada anggota prolanis seluruhnya tinggal bersama anggota keluarga baik kelompok kontrol maupun kelompok perlakuan (100\%). Hal ini dapat memberikan 
Jurnal Kebidanan Harapan Ibu Pekalongan

gambaran bahwa lansia anggota prolanis memiliki dukungan keluarga yang baik. Pelaksanaan senam prolanis di Puskesmas dengan seluruh anggota lansia membentuk sebuah perkumpulan sosial dimana disana lansia dapat berinteraksi dan berkomunikasi sesama anggotanya, sehingga membentuk kelompok sosial yang saling mendukung sehingga lansia tidak merasa kesepian dengan dukungan sosial yang ada.

Selain itu program prolanis umumnya diikuti lansia dengan penyakit degeneratif baik anggota BPJS maupun masyarakat umum seperti hipertensi dan diabetes mellitus. Melalui keikutsertaan dalam kegiatan senam prolanis yang setiap pelaksanaannya dilakukan pengukuran tekanan darah dan berat badan, setiap bulannya di tambah dengan pemeriksaan kadar gula, cholestrol dan urine acid, membuat penyakit yang diderita lansia menjadi terkontrol. Jadi penurunan skor kecemasan pada lansia disebabkan oleh interaksi sosial saat snam prolanis dan gerakan senam prolanis yang meningkatkan penyerapan oksigen sehingga memicu hormone endrofin untuk meningkatkan rasa tenang dan senang pada lansia.

\section{Kesimpulan dan Saran}

Sebelum melakukan senam prolanis sebagian besar lansia memiliki skor kcemasan rata-rata 19,76 (kecemasan ringan). Sesudah melakukan senam prolanis hampir setengahnya lansia memiliki skor kecemasan rata-rata $\quad 18,10$ (kecemasan ringan). Terdapat pengaruh senam prolanis terhadap kecemasan lansia di Puskesmas Sumberbaru dengan nilai signifikansisebesar $0,000 \quad(\mathrm{p}<$ $\alpha=0,05$ ). Hendaknya pihak Puskesmas melakukan sosialisasi pelaksaan senam dan jadwalnya prolanis agar lebih banyak lagi lansia peserta BPJS dan umum yang mengikuti serta menyediakan hadiah hiburan, menyarankan lansia untuk senam dirumah, perawat menggunakan HARS untuk mengkaji kecemasan lansia dan menggunakan senam prolanis untuk intervensi kecemasan serta selanjutnya penelitian selanjutnya menggunakan metode quasi-eksperimen dengan kelompok kontrol dan kelompok perlakuan sehingga hasil penelitian akan lebih baik dan lebih sempurna.

\section{Daftar Pustaka}

[1] K. Anggraini and Widiani, "Hubungan Dukungan Sosial Dengan Tingkat Stres Pada Lansia Pada Lansia Di Posyandu Bendungan Desa Landungsari Kecamatan Dau Malang," Nurs. News (Meriden)., vol. 2, no. 3, 2017.

[2] Asmadi, Teknik Prosedural Keperawatan Konsep dan Aplikasi Kebutuhan Dasar Klien. Jakarta: Salemba Medika, 2012.

[3] Badan Pusat Statistik, Statistik Penduduk Lanjut Usia 2018. Jakarta: Badan Pusat Statistik, 2018. 
Jurnal Kebidanan Harapan Ibu Pekalongan

[4] N. Herawati, "Pengaruh Senam Lansia Terhadap Tingkat Kecemasan Lansia Di Panti Sosial Tresna Werdha Sabai Nan Aluih Sicincin Kabupaten Padang Pariaman Tahun 2013," J. Keperawatan Jiwa, vol. 2, no. 2, 2014.

[5] Institute on Aging, Anxiety in the Elderly: Symptoms and Restorative Strategies. 2018.

https://blog.ioaging.org/men tal-illness/anxiety-in-theelderly-symptoms-andrestorative-strategies (accessed Jul, 22 2020)

[6] Khamida dkk, "Senam Tai Chi dalam menurunkan kecemasan Lansia," J. Ners dan Kebidanan, vol. 5, no. 3, 2018 .

[7] S. N. Kholifah, Keperawatan Gerontik. Jakarta: Kementerian Kesehatan Republik Indonesia, 2016.

[8] C. Okonkwo, Managing Anxiety Disorders in a Geriatric Population. 2017. http://www.grhosp.on.ca/ass ets/documents/2017-day-inpsychiatry/ManagingAnxiety-disorders-inGeriatric-Population-Dr.Okonkwo.pdf (access Jan 9, 2020)

[9] B. de Oliveira, L. da S. S. Castelo, and Dkk, The effects of physical activity on anxiety, depression, and quality of life in elderly people living in the community, Trends Psy. 2019.

https://www.researchgate.ne t/publication/330890350

(access Jan, 9 2020)
[10] J. A. Pasco and Dkk, "Habitual physical activity and the risk for depressive and anxiety disorders among older men and women," Int. psychogeriatrics, vol. 23, no. 2, 2011.

[11] G. S. Redjeki and Herniwaty, "Faktor - Faktor yang Berhubungan Dengan Kecemasan Lanjut Usia Di Puskesmas Johar Baru Ii Jakarta," J. Kesehat. Saelmakers Pradana, vol. 2, no. 1, 2019.

[12] J. Schuurmans and A. van Balkom, Late-life Anxiety Disorders: A Review, Curr Psych. 2011.

[13] G. W. Stuart, Principles and Practice of Psychiatric Nursing 10th Ed. Missouri: Elsevier, 2013. 